\title{
Religious Extremism in the Republic of Tajikistan: Criminal and Criminological Problems
}

Validzhon Abdukhalimovich Abdukhamitov

Umed Abdufatokhovich Mansurov

Hurshed Tolibovich Nasirov

Azizmat Chorshanbiyevich Chorshanbiyev

Russian-Tajik (Slavic) university, M. Tursunzade St. 30, 734025, Dushanbe, Republic of Tajikistan

Doi:10.5901/mjss.2015.v6n6s3p258

\section{Abstract}

In the article, it is analyzed regulations of the penal legislation of the Republic of Tajikistan about the fight against religious extremism. Authors systematically investigate the nature of extremism and show communication of its manifestations with psychological, spiritual and moral, socio-political factors. Extremism - today one of the most dangerous phenomena of social life destabilizing the political system and menacing to life activity of citizens. It is considered the reasons and conditions of participation in crimes of extremist character, criminal law action measures on crime of extremist character are considered, and also the questions concerning prevention of extremism in socio-political life of modern Tajik society reveal. The essence of this crime and its signs reveals. It is noted about the public danger of the specified crime and its threat to national security in Tajikistan.

Keywords: religion, Islam, extremism, crime, criminal liability.

\section{Introduction}

In Tajikistan, there were cardinal changes connected with changes in the economy and the state system of the country. Along with many positive processes in the Post-Soviet period of development of Tajikistan began to be shown the tendency and negative character: tough race for power and state-owned property, growth of organized forms of crime, corruption, separatism, political and religious extremism, etc. The religion always took the important place in culture, and interest of researchers in religious problems does not weaken still. At the present stage the attention of investigators to the phenomenon of religious extremism that directly influences the functioning of all spheres of life activity of the Tajik society amplifies. Requirement causes the importance of studying will explain the social, political, cultural phenomena occurring at the individual and society levels, and theoretical interest predetermines need to comprehend the extremism phenomenon completely.

Questions of the fight against religious extremism purchased special relevance in modern society. It is enough to give cases of long-term oppositions and vigorous activity of extremists in Afghanistan, Egypt, Chechnya, Serbia, Syria, Lebanon, Turkey, Pakistan and some other countries when thousands of people suffered from the extremist groups of crimes made by organizers, heads and participants, material and cultural wealth was destroyed, threats of repetition of acts of terrorism, taking of hostages, murders constantly keep society in suspense, and citizens - in fear. Therefore, it is possible to state, that the threat to security in Tajikistan becomes more and more real. Naturally, that the similar situation demands immediate actions from the state, mobilization of all means for suppression of similar actions of extremists. It defines specifics of the crimes provided as directly by St. 3071, 3072, 3073 and 3074 the Criminal Code of Republic of Tajikistan , connected with the organization of extremist communities, the management of it or participation in it, and also commission by members of such criminal associations of other crimes.

As the statistics testify, the essential factors increasing the public danger of extremist groups in the Republic are obviously unfortunate trends of development of this type of crime in the last decade of the expired century.

So, if, according to statistical data of the Ministry of Internal Affairs of the Republic of Tajikistan, in 2010 on the republic only 1 fact of the organization of extremist community, in $2011-3,2012-8,2013-9,2014-43$ was registered.

These circumstances dictate need of theoretical and practical development of many questions concerning 
counteraction to religious extremism, the maintenance of signs of structure of this act, its qualification, the prevention and restriction from other adjacent structures of crimes, etc.

The modern period of development of the Republic of Tajikistan is characterized by forming of political, social, economic, spiritual basis of public and state life. There is the updating of world outlook views, universal values, the rights and freedoms of the person, the democratic forms of government, the safety of society and state are reasonably put in the forefront.

Thus, all above circumstances testify to relevance and to the scientific and practical importance of research of problems of counteraction to religious extremism in the Republic of Tajikistan and allow to carry the considered problem to actual as in scientific, and on the practical level. Above noted constitutes, the extremism problem in some significant and staticizes its conceptual analysis.

Estimating the modern level of development of domestic science in the field of researches of the theory and practice of religious extremism, the role and place of the religious factor in public life, it should be noted, that the integral concept considering specifics of these processes in Tajikistan until it is poorly developed. Insufficiently accurately, and at times it is biased and inconsistent estimates of the place and the role of Wahhabism in structure of religious relationship, and also in political life of our region, the origin here of the specified current in Islam, methods of its regulation and management are given. Also, there is no criminological research on this issue, directly related to the situation in Tajikistan, which is due to its multi-confessional area of conflict increased.

In the Russian Federation, the attention was paid to separate aspects of the legal analysis of religious extremism. It is possible to refer works of such Russian scientists to them as Yu.M. Antonyan, V.N.Arestov, V.A. Burkovskaya, L.D. Gaukhman, V. S. Komissarov, V. N. Kudryavtsev, N. F. Kuznetsova, V. V. Maltsev, A.V. Pavlinov, V. I. Radchenko, A.I. Raroga, N. V. Stepanov, T.A. Skvortsova, M.C. Fokin, S. N. Fridinsky, etc.

But at the same time the multilateral analysis of problems of counteraction to religious extremism continues to remain debatable as many criminal legal issues of counteraction of religious extremism are a little developed, that does not promote unambiguous application of the penal statute in practice.

In the Republic of Tajikistan, there were no researches devoted to counteraction to religious extremism. On other specialties, there are works connected with the operational-search activity of law and special bodies under the signature stamp "confidentially". The separate aspects of religious extremism and types of crimes connected with its activity received reflection in works of domestic scientists: U.G. Abdukhalikova, S. Kosimov, M. M. Mullayev, A.H. Imomov, G. S. Satarov, T.Sh. Sharipov, etc.

In the Republic of Kazakhstan separate aspects of extremism received reflection in works of the Kazakh scientists: E.O. Alaukhanov, I.Sh. Borchashvili, U.S. Dzhekebayev, G.R. Rustemova, etc.

The similar situation with the research of extremism also developed in the Kyrgyz Republic. Some issues of the fight against extremism are touched in works of the Kyrgyz scientists: K.I. Dzhayanbayev, K.Sh. Kurmanov, L.Ch. Sydykova, B. G. Tugelbayeva, N. N. Sulaymanova, and others.

Relevance and diversity of the considered problem and its insufficient readiness in the Republic of Tajikistan caused the choice of the subject of this article.

\section{Materials and Methods}

This research is executed by the scientific subject of law department of the Russian-Tajik (Slavic) university: "Fight against religious extremism in the Republic of Tajikistan and the Russian Federation: problems of the theory, legislation and practice". Scientific novelty of research is characterized by the development of the modern concept of religious extremism, criminal and legal and criminological bases of counteraction to this phenomenon are formulated. This work is one of the first attempts to scientific research in the Republic of Tajikistan of the problem of the fight against religious extremism at the monographic level.

Scientific novelty of research also consists in that, that the concept and the technique of research allowed to formulate the concept "religious extremism" that formed the basis for correction of the object of structuresc Art. $307^{1}$, $307^{2}, 307^{3}, 307^{4}$ of Criminal Code of Republic of Tajikistan and their restriction from adjacent structures.

In work the analysis of feature of foreign legal models of fight against religious extremism and its separate types is carried out; the criminological characteristic of public consciousness and tendencies of development of religious extremism in Tajikistan is given; are described the factor complex of religious extremism; the state and shortcomings of the modern legislation of the Republic of Tajikistan regulating different aspects of fight against religious extremism are characterized; the criminal and legal and criminological characteristic of the main manifestations of religious extremism is given. 
Besides, questions of qualification of the crimes integrated to religious extremism, including, arising from the competition of criminal precepts of law found additional permission in article; recommendations about application of the corresponding criminal precepts of law in investigative and court practice is developed; suggestions for improvement of the current legislation regulating responsibility for the crimes that are the subject of this research are put forward, formulated and proved.

Also in work the main directions of improvement of criminal legal and special criminological measures of the fight against religious extremism are revealed; set of specific changes and additions in the legislation of the Republic of Tajikistan is offered.

The practical importance of this research is defined by the compound of suggestions for improvement of the criminal and legal and special criminological measures of fight against religious extremism intended for the legislator, bodies of judicial authority of Republic of Tajikistan, the Prosecutor General's Office of Republic of Tajikistan and others law and the Republic of Tajikistan monitoring bodies allocated with powers in the field of fight against extremism. The practical importance of work also consists in that, that theoretical conclusions, offers and recommendations of the competitor can be used at implementation of legal reform and preparation of regulatory, legal acts in the field of ensuring the state and national security.

Results of research can be used in rule-making and law-enforcement activity, when carrying out further scientific researches on this problem, when teaching disciplines on criminal law, criminology and special courses on the corresponding perspective in educational institutions of the legal profile of the Republic of Tajikistan. The data obtained as a result of research can be also used for further improvement of the law on fight against extremism.

The public relations arising in the course of safety of the state from threat of religious extremism and pattern, allowing to define the main directions of criminal and legal and criminological character in fight against religious extremism act as object of research.

The object of research was the phenomenology and the factor complex of religious extremism; criminal and legal and criminological bases of counteraction to this phenomenon; the legal and other literature concerning problems of the fight against religious extremism.

The dialectic method of knowledge of the social phenomena and processes allowing to consider them in permanent development, close interrelation and interdependence became the methodological basis of research. During research logical, system and comparative and legal methods were applied, synthesis of the judicial and investigative practice of the Republic of Tajikistan was carried out.

It is subjected to the analysis also this legal Statistics of the Republic of Tajikistan.

\section{Results}

In the scientific environment of the attempt to the analysis of the genesis of extremism religious within the certain concept is the rarity. At disclosure of genesis of the definition "religious extremism" research of social, its political sources, and also specific features of ideology, practice of those certain faiths which most in it is often shown is necessary.

Concerning the nature of this different phenomenon judgments express. For example, S. N. Fridinsky believes about rather a difficult phenomenon to this phenomenon in the type leaving it to sources and available the ethnic question (Fridinsky, 2004).

Construction of constructions from skulls of the killed people in the era Tamerlane and Genghis Khan, execution (inquisitorial) the 13th century made in Spain, use of gas chambers by fascists in Germany, explosion of buildings of the World shopping center to the USA, religious-based disputes in Pakistan, India, Iraq, Sri Lanka, Bangladesh, Somalia, Israel, Nigeria, Afghanistan, territories of Palestine, Egipete, Syria, Libya are separate examples of extremism at the heart of which were available and mixed up, both national, and social and religious arguments.

At first historians, philosophers, sociologists and political scientists closely started being engaged in studying of this antisocial phenomenon demanding effective measures of counteraction (Arestov, 1987; Romanov, 1991; Kononov \& Romanov, 1994; Verkhovsky \& Pine, 1996; Nightingales, 1998; Verkhovsky, Mikhaylovskaya \& Pribylovsky, 1999; Dobayev, 2000; Wolves, 2002; Ravens, 2003; Kovalyov, 2003 \& Mukhabbatov, 2004), and specialists in the field of law (Peacocks, 2008; Fridinsky, 2003; Gorshenkov, 2008; Uzdenov \& Pudovochkin, 2008; Nazirov, 2007). Meanwhile, the difficult character of the nature of the most extremist phenomenon complicates to give legal definition to the concept "religious extremism". Repeatedly ongoing efforts to reveal the essence of religious extremism still cause discussions.

The insight of the definition "extremism" in the science of criminal law and classification of its versions generates different debates, and also is ambiguous in the science of criminal law of Tajikistan and foreign criminal law. Despite the fact that considerable literature is devoted to concepts of terrorism and extremism, at the present stage there is no 
uniform and their established interpretation and treatment. The problem is and that the population of the country has a weak idea of these phenomena.

This concept was used in mass media in Soviet period, however many citizens of Tajikistan on our polls for 2014 $36 \%$, answering the question to explain value of this phenomenon, note, that have no idea of it $(26 \%$ - "I hear for the first time"). Two per cent of respondents, unable to explain it, have expressed their opposition to extremism - "it is not good, is prohibited by law," "dirty word." "I know" 19\% of respondents, answered. The considerable part of citizens (37\% across Dushanbe, $23 \%$ over the country) associates extremism with aggressive methods of the fight for something.

Researchers refer these concepts to the most ambiguous and multidimensional, that is explained by complexity, the versatility and historical variability of the phenomena.

Thus, for refining of essence and determination of religious extremism mainly it is necessary to stop on consideration of the available approaches to determination of the definition "extremism" as the extended sense of this concept is output from its etymology.

The etymology begins since antiquity. The term comes from Latin words «extremitas», i.e. "extreme", and respectively «extremus» - "extreme"(Ermert, 2003).

All above understanding of religious extremism in our opinion can only be opened at clarification of the following views.

1. In modern scientific researches investment to the term "extreme" with such offers and values with which the definition "extremism" has the insignificant general often seems. For example, D.E. Nekrasov suggests understanding as extremism extraordinary, nonconventional, not accepted, and also irreconcilable, resolute and exclusive commitment to views and measures, being based only on Latin translation of extremism. A.G. Hlebushkin adheres to the similar point of view, noted about value of the term of the extreme as to understanding - going beyond any framework and regulations, and the extremism from his point of view is defined as extreme degree of neglect (Hlebushkin, 2007).

Most likely, methods of determination of etymology "extremism" for the purpose of necessary legal treatment sometimes approach to semantic change of the available determination "extreme", that as a result leads to emergence of the new term.

Latin terms «extremitas» and «extremus» were used in the ancient time for the description of the most remote position concerning any point of measurement or starting point. For example, term «Extrem itas Mundi» meant "world border"(Ermert, 2007). Also, it is not excluded, that the Latin term «extremus» comes from the Greek root «trema» («opening», «glade»). In that case the one who left borders of strengthening of the policy could be understood as the derivative term "extremer" (греч. «роlis») to refuse internal duties in relation to the values accepted in it not to be to it involved anymore (Ermert, 2007).

2. In the dictionary of Russian the extremism means "commitment to extreme measures and views (usually in policy)" (Ojegov, 2002). In political sense under extremism means aspiration to solve problems, to achieve effective objectives using the most radical methods, including all types of violence and terror" (The short political dictionary, 1989). These determinations allow to consider extremism as one of the forms of radical denial of the existing public regulations and rules in the state from individuals or groups (Arukhov, 2001). G. N. Chebotaryov agreeing with such determination notes, that the extremism - from the point of view of morals and moral is understood as angrily as in it the ideas and opinions that are considerably differing from commonly accepted in the society of moral regulations and rules, often leading to commission of illegal, violent acts are preached (Chebotaryov, 2011). At the same time etymological value can be only the basis for understanding of this or that phenomenon because allows to receive at best the most general idea about the considered phenomenon, is not always suitable for practice, including law-enforcement. For example, O. M. Hlobustov and S.G. Fedorov under extremism treat aggressive behavior (spirit) of the personality which most essential external manifestations are, first, intolerance to opinion of the opponent oriented to the commonly accepted regulations in this society; secondly, tendency to acceptance of extreme (power) versions of the problem resolution; thirdly, rejection of consensus as value and business instrument of everyday activity; in the fourth, rejection of the rights of the personality and her as worthinesses (Hlobustov \& Fedorov, 2000). However in our opinion, the offered determination is indistinct and does not reproduce all features of this difficult phenomenon. It should be noted, that it is not clear which views it is necessary to recognize "extreme" and what - are not present and who will define whether some specific views are extreme. What - or final criterion for interpretation of this definition is not developed yet as the conceptual analysis of the phenomenon of extremism in general and the creation of its theoretical models just start including in the research plans. Thus the concepts "views" and "measures" bear in themselves different semantic loading. With the certain approach, it is possible to 
understand the ideology, ideological belief not always connected with any practical, especially illegal actions as "views." Moreover, "measures", in turn, provide a commission of any specific actions including violent, directed on the overthrow of the constitutional system or destabilization of the country situation. For determination of the known phenomenon still there are no conventional determinations, there is no consensus about that, that designates and in what cases they can operate. As for determination of extremism with the linking of the words "commitment to extreme measures and views (usually in policy)", we will note, that the extremism usually contacts policy. V.A. Burkovskaya mentions it in the research, mentioning that, that antiextremist laws of the states - participants of the CIS are directed on fight for such crimes that generally are expression forms first of all of political extremism" (Burkovskaya, 2005). Je.W. Kuntz, notes about the use of religious slogans for incitement of international hostility and the aggravation of the conflicts between different political forces in society (Kuntz, 1998).

L. Syukiyaynen approves the nature of extremism, see, as a rule, in the orientation on the achievement of political goals (Syukiyaynen, 2002). At our look if the policy affects practically all spheres of life of society, respectively, acts as that in various personal forms, will become obvious, the field of activity for extremist groups is how extensive. However, it is necessary will note, that the extremism can also be out of policy: the address of attention only on political to the direction of extremism it is wrong.

3. In the dictionary of German, the extremism is understood as the extreme position; direction; socially intense struggle (Duden, 1977).

Proceeding from essence of the initial concepts "extreme", we cannot understand also extremism as certain "commitment" (Nekrasov, 2007), emphasizing its psychological nature, or any "neglect to the commonly accepted regulations" (A.G. Hlebushkin), accenting its interpretation on the social and legal sphere as there is only the sign of the phenomenon uncertain in essence, and the pair semantic concept defining it the contents no.

Thus, if to approach extremism etymology to essence of concept «extremus», it is necessary to understand the term designating the limit, edge, border of rather certain space, temporary and other sizes, which are conditionally taken for "normal" as extremism. In such understanding, the extremism is identical to the concept "extremum" (from Latin «extremum») - "extreme". Also, the last concept is single-root with concepts «extremitas», i.e. "extreme", and «extremus» - «outermost». It testifies to that, that initial Latin concepts do not open essence of the studied phenomenon at all, and only designate its quality or property. Without the establishment of pair concept that availability assumes the term "extremism," it is impossible to understand the maintenance of the last. It suggests the idea of that that sources of modern understanding of extremism find the roots not in antiquity, and in later time within the specific historical period.

Because of different judgments concerning the determination of concept of extremism, two positions were created.

Supporters of the first position consider that independent extremism manifestation is possible to consider as the acts, which are based on the certain ideology and extremist ideology in the separation from the corresponding acts.

So, B. I. Galperin investigating religious extremism, noted, that the extremism is the ideology that is directed to achievement of goals by means of commission of terror, violence, murders and other types of aggressive activity" (Galperin, 1989).

According to V. Kovalyov, any extremism shall also include the point of view, as a rule, not commonly accepted. He criticizes concepts in which, distinctions between ideals are carried out, seeing in its remnants of the Soviet ideology when considered, that it is possible to think anything but to extend the views, it was forbidden. However, unexpressed belief is not belief in his opinion (Rzhev, 2004).

The above-stated opinions are objected quite reasonable, in our view, by the supporters of the second position inclined to see in extremism only set of certain acts. In particular, O.P.Orlov at disclosure of concept extremism suggests being guided by the approach where at the heart of determination is available - an illegal act. He does not agree with authors who at one level put at the determination of extremism world outlook basis of ideology, but not criminal actions. Thus, O.P.Orlov, the criterion of notes against what it is necessary to fight, there are not actions, but ideas. Here, in his opinion, there is also the threat for their free distribution. The similar argumentation, in our view, is submitted very convincing. Still C.B. Poznyshev wrote, that "... cannot be the crime of thought, belief, belief..." (Kozlov, 2004).

The essence of the second approach to the determination of extremism consists in aspiration of researchers to define this phenomenon through set already recognized illegal acts. 
For example, S. N. Fridinsky considers, that it is necessary to understand the activity or appeals to it certain subjects directed on establishment of the only ideology as state as extremism; on separate crimes against bases of the constitutional system and safety of the state (Fridinsky, 2003).

Now the use of the term "religious extremism" is necessary for the adequate assessment of so-called "collisions of civilizations".

4. The religious extremism demands the comprehensive analysis because such line as versatility is inherent in it. For example, it seems to us which is insufficient, worked the point of view H.A, Romanova. It defines extremism in the field of religion as cultivation of the intolerant attitude towards believers of other religious faiths, violent capture of their cult constructions, incitement of hostility among believers, crimes against life, health and constitutional rights of priests and believers of other religions (Romanov, 1997). In our opinion, the offered H.A. Romanov determination is, in fact, "the external orientation" of religious extremism because there are essential extremist manifestations in one faith, between different currents.

Due to the different interpretation, certain authors suggest considering determination "religious extremism" in narrow and in wide meanings of the word. "The extremism is the simplification, banality, bringing down to the elementary elements. One-dimensional, the rectilinear vision of the world is always peculiar to carriers of totalitarian culture" (Kruglov, 2003).

The narrow treatment of religious extremism assumes activity of political parties and movements contrary to the law, and special subjects as officials and citizens, directed by violent change of the constitutional system and initiation of race and social hatred (Cowsheds, 1990). In addition, N. Namatova holds the same opinion, nothing about that, that the religious extremism is the activity directed at violent change of the political system violation of the sovereignty and territorial integrity of the state (N. Namatov). V. N. Arestov defined religious extremism as "activity of antisocially adjusted elements covered with religion and certain religious fanatics (Arrests, 1987). A. Zhuravsky considers religious extremism as the extreme form of development of religious fundamentalism. The extremism can further and become terrorism, but the researcher nevertheless is not confident in that, that it is possible to recognize the crime as terrorism religious. The author is convinced, that the concept "religious extremism" shall be used despite not political correctness (Zhuravsky, www.sedmiza.ru).

A. Verkhovsky offers different options for the use of the term, points to inevitable contradictions and, having passed to possible legal effects, urges to use the term "extremism" (including and religious) in sense rather narrow to reach the most efficient and safe law enforcement for citizens (Verkhovsky, www.religion.ng.ru). S. N. Fridinsky believes that religious the extremism is the intolerance about dissidents to representatives of the same or other religions (Fridinsky, 2003).

Yu.M. Antonyan, considers does not agree with the opinion of a relative that, that only the racial, religious or national movements can be the maintenance of extremism. He emphasizes, at the present stage there are movements, which do not rely on views of any religious group, on the contrary, they can ignore them, but thus demand extremist social and political requirements and resort to extremist political actions (Antonyan, 2008).

Emmanuel Sivan emphasizes, that "radical Islam" which should not be identified with Islam at all in general acts as the prime vendor and the chief distributor of extremism and terrorism (Eberta, 2003). In the theoretical analysis of sociopolitical processes and the phenomena, use of the definition "the religious extremism" as the form of expression of social meanings, at first sight, seems exact. However, if to consider all structure of the religious complex and its functioning in the context of spiritual life of society, it will be visible, that it is necessary to examine also the liberty principles of conscience which are not forbidding upholding of the views, but including and restrictive requirements including to the form of the statement of the positions, freedoms connected with preserving, health and life of people.

Nevertheless, it is impossible to ignore the different phenomena that, on the one hand, are extremist and even terrorist, and with another - are directly connected with any religious direction. In opinion, A. Ignatenko the Islamic extremism does not exist, and there are social groups which implement the tightly egotistical views, under cover of Islamic extremism there are particular groups that are according to the real contents not religious - not Islamic, but they are covered with Islam act under Islam banner. Especially malicious movements by Islam mask (Ignatenko, 2004). Agreeing with A. Ignatenko's opinion, A. Korovikov notes "Islamic extremism" - the term quite subjective. It even has no commonly accepted determination (A.V. Korovikov).

Thus, on the basis of the considered determinations of religious extremism and results of our research we came to the conclusion, that it is necessary to understand commission of illegal acts as religious extremism, characterized by tendency to the most radical on belief and views to forms interpretation of the dogmas randomly declared true, differing from commonly accepted in the society of moral regulations and rules, and also distribution of the opinions in illegal methods for implementation of the established purposes and tasks. 
The law of the Republic of Tajikistan "About fight against extremism" of December 8, 2003 No. 69 (the Law of the Republic of Tajikistan, 2003) for the first time in the history of Tajikistan fixed the legal definition of the concept "extremism" in the form of extremist activity. However, to recognize, that the Law of Republic of Tajikistan "About Fight against Extremism" as essentially new in the legislation of Tajikistan, so to exaggerate its role as regulatory legal acts to some extent mentioning measures of fight against extremism in the Republic of Tajikistan was already acting before its acceptance.

Therefore, the laws directed on the fight against extremism in the Republic of Tajikistan before the adoption of the law of Republic of Tajikistan "About Fight against Extremism" are 1. Constitution of the Republic of Tajikistan, 2004. 2. The law of Republic of Tajikistan "About Religion and the Religious Organizations" of December 1, 1994 (as of May 12, 2001) become invalid with maintaining in action on March 26, 2009 for the new Law of Republic of Tajikistan "About the Freedom of Worship and Religious Associations" (the Law Republic of Tajikistan, 2009) 3. The criminal code of Republic of Tajikistan of May 21, 1998 (The Criminal Code of the Republic of Tajikistan, 2004). 4. The law of Republic of Tajikistan "About Public Associations" of May 23, 1998 (as of May 12, 2007) which became invalid with maintaining in action on May 12, 2007 for the new Law RT "About Public Associations" (the Law of the Republic of Tajikistan, 2007). 5. The law of Republic of Tajikistan "About Political Parties" of November 13, 1998 (the Law of Republic of Tajikistan, 1998). 6. The law of Republic of Tajikistan "About Fight against Terrorism" of November 16, 1999 (the Law of the Republic of Tajikistan, 2007).7. The Shanghai Convention on the fight against terrorism, separatism and extremism of July 15, 2001 (in an edition of the Protocol of September 5, 2003) (Shanghai Convention on Combating terrorism, 2003) 8. The resolution of Parliament of the Republic of Tajikistan on ratification of the agreement (The agreement between the Republic of Tajikistan, the Republic of Kazakhstan, the Kyrgyz Republic and the Republic of Uzbekistan on joint actions on fight against terrorism, political and religious extremism, the transnational organized crime and other threats to stability and safety, 2000) about common actions on combating terrorism, political and religious extremism, the transnational organized crime and other threats to stability and safety.

Apparently, the legal base necessary for the protection of the constitutional system of RT from criminal encroachments, both existed earlier and continues to exist now almost in the invariable type. Besides, unsuccessful normative and legal determination of the specified concepts led to the emergence of the collision of this law and provisions of the Criminal Code of the Republic of Tajikistan. Moreover, in the current legislation there is no general legal determination of extremism. It does not operate, naturally, and the term "religious extremism".

In our opinion, the sense of development of the Law of Republic of Tajikistan "About Fight against Extremism" consisted in creation of the uniform regulatory legal act in the field of fight against different forms of extremism. In general, this idea seems to us quite reasonable as makes the legal base of fight against extremism impressive, layer of the penal legislation in which it is not simple to subjects of legal relationship to be guided. Besides, fixing of the main terminology in the field of fight to illegal manifestations of extremism theoretically can facilitate considerably formulations of rules of law in the industry legislation; exclude different understanding of their treatment, that it is necessary for creation of the correct and consistent legal basis of counteraction of extremist activity in the Republic of Tajikistan.

However, despite the indisputability of such arguments seeming, at first sight, we consider that normative and legal determination of extremism cannot be interpreted somehow differently, than in political science. More precisely, options of legislative determination of extremism can be much, but depart from political and even partly from the philosophical essence of this phenomenon, in our opinion it will not turn out. Otherwise, the essence of extremism should be distorted criminal legal measures of influence therefore will be directed as already earlier it was noted, on counteraction to obviously pseudoscientific phenomenon. On the other hand, political interpretation of extremism in the legislation as "hostility to democracy" too does not make sense as the content of such determination can be opened fully only in the appropriate scientific sources. Proceeding from it, fixing of the concept "extremism" of the law urged to carry out the coordinating legal function seems to us the measure, which is a little distracted, from reality. Determination of such concept is possible, in our opinion, in conceptual regulations, but, from it will not become legal by nature.

\section{Discussion}

Studying of the Law of Republic of Tajikistan "About Fight against Extremism" shows, that it is aimed at the fight with religious-political, but not with religious extremism. The contents of precepts of law of this law convince, that extremism the phenomenon only of the strategic order, more versatile, than terrorism and, therefore, means of counteraction are offered it different, including the softest (for example, official caution). Other forms, more dangerous, require different responses, especially if associated with a violent impact on power. It should be noted, that, proceeding from legislative determination, extremist activity should not influence only the power. It can also be provided by impact on social groups, 
representatives of this or that nationality, race, religion, kindling discord and hostility, humiliating national advantage. The existing called law of Republic of Tajikistan generated the set of questions.

That is located at the heart of the concept of the Law of Republic of Tajikistan "About Fight against Extremism" from the point of view of the direction in the fight against extremism. That means narrowing, at least, at first sight, determinations of extremism.

More likely, formatting of the law takes place and inclusion former composed, their dissolution in the first two block components current is meant.

It is necessary to take into account and, that information, technical and mutual support of terrorists, extremists and separatists constantly extends. In Tajikistan, the foreign literature of religious character on Arab began to arrive and, is rarer on Persian languages (most often illegally) in local languages where it was possible to notice interpretation of Wahhabi sense. For example, tactics and strategy of extremists were stated in such books and benefits as "The Islamic system", "the Way of Hizb-ut-Tahrir", "Managerial control", "Structure of the power in Islam".

The analysis of the practice of investigation of criminal cases shows, that some persons, who assassinated used the data received from similar sources by the preparation of the crime. It testifies to the public danger of distribution of such information (Luneev, 2005).

However, similar materials are not extremist, proceeding from provisions of Art. 3 of the Law of Republic of Tajikistan "About Fight against Extremism", and, therefore, their distribution, production remain outside regulation of this document.

At last, we will provide conclusions from the above:

1. The religious extremism - is the independent type of extremism having owned determination and phenomenology.

2. The religious extremism can take place and out of policy: concentration of attention only to the political orientation of extremism is wrong.

3. Growth of criminal activity is observed (needy persons, minors, women, law enforcement officers are involved in the extremist criminal relations).

4. Particular attention, in our opinion, also should be turned on the need of precautionary scheduled maintenance on liquidation of the religious and extremist, extremist and terrorist sites on the Internet. We believe that law enforcement agencies shall conduct systematic precautionary scheduled maintenance on prevention of placement in the global network of similar propaganda materials.

5. Create in Tajikistan system of expert organizations, on the materials and affairs connected with production and distribution of products directed on Incitement of hostility or hatred on the national, parochial or religious sign.

Prepare the list of extremist materials. In this list shall materials, which are recognized by court extremist, join. It is necessary to consider both the circulation of products and the method of its production and distribution. We believe that forming of the list shall be performed not automatically, and the centralized body, which part representatives of state agencies, public organizations, and scientific community, would be. About the existence of such list sellers of literature, video, and audio products, employees of libraries shall be surely acquainted.

\section{Conclusion}

The research conducted by us allows to formulate certain theoretical conclusions, to make concrete proposals for improvement of the penal legislation and recommendation about counteraction to religious extremism, and also to recommend measures for the prevention of the specified crime.

As it was shown in this work, the religious extremism represents the difficult phenomenon which is implemented in four forms: as condition of consciousness, ideological system, set of actions for its implementation, and also as organizational structures.

Proceeding from existing today in the Republic of Tajikistan to the criminal legal doctrine and concept of the rights and freedoms of the person and citizen, only acts are subject to prohibition and punishment by means of the penal statute, and the ideology and the condition of consciousness can be reflected (to some extent) only in quality of motives or the purposes of actions ("based on racial, national or religious hatred or hostility").

However answering motives and to the purpose understood in a broad sense as a system of motives of the person to activity can "turn" any criminal action into an extremist.

The specified circumstance also caused our appeal to the analysis of the condition of public consciousness. Relying on data from the different sociological researches on questions of tolerance executed by other specialists, and also considering the results received by us during polls of students of legal higher education institutions and employees of 
law enforcement agencies we came to the following conclusions and offers.

Research showed, that the religious extremism - is the independent type of extremism having owned determination and phenomenology.

The modern anti-extremist legislation of the Republic of Tajikistan is extremely difficult and inconsistent. It is possible to give $\mathrm{h}$ as the example. The 3rd Art. 3 of the Law of Republic of Tajikistan "About Fight against Extremism" where under extremist activity the legislator counted to understand the activity of legal or physical persons. This provision of the delivery of the law contradicts Art. 22 of the Criminal Code of Republic of Tajikistan according to which criminal liability only the responsible physical person, but not the legal entity is subject. In our opinion, in such type the law it is objectively not capable of providing the sufficient level of efficiency fight against manifestations of religious extremism. And for the purpose of elimination of this contradiction we suggest to change Art. 3 of the Law of Republic of Tajikistan "About Fight against Extremism", having added the words "activity" with words of "heads".

Work convinces about need of creation of Tajikistan system of expert organizations, on the materials and affairs connected with production and distribution of products directed on Incitement of hostility or hatred on the national, parochial or religious sign.

It is necessary to eliminate insufficiency of legislative development of measures of counteraction on religious extremism, in our opinion, by the preparation of the list of extremist materials. In this list, shall materials, which are recognized by court extremist, join? It is necessary to consider both the circulation of products and the method of its production and distribution. About the existence of such list sellers of literature, video, and audio products, employees of libraries shall be surely acquainted.

Regulations of the penal statute, especially after adjustment by the Law of December 8, 2003, at first sight, are represented rather efficient. However, the resource of the penal statute in the fight against religious extremism is very limited. In this regard as shows experiment including foreign, the shift of accents from criminal law in the area of a criminal trial can be rather perspective.

Given the major threat to society and the state of any extremist crimes, the punishment for these acts should be constructed in such a way that among these actions was not a minor offense.

The carried-out systematization, generalization, the critical analysis of judicial and investigative practice on manifestations of religious extremism in Tajikistan revealed the ripened need of explaining the highest degree of jurisdiction on this problem in the form of the Resolution of Plenum of the Supreme Court of the Republic of Tajikistan.

\section{Acknowledgement}

The group of authors of this scientific article thanks the Rector of the Russian-Tajik (Slavic) University, Professor Salikhov N.N. for support and the help in the publication of this article. Authors also express gratitude to colleagues of the university, in particular, the doctor of jurisprudence, professor Abdullaev M.A., to professor Shambezod's H.Dzh. for the help and support by the preparation of the article.

\section{References}

Duden (1977) Das grobe Worterbuch der deutschen Sprache. B.2. Mannheim-Wien-Zurich; Dudenverlag.BibliografhichesInstitut. pp. 779.

Ermert, Matthias (2003) Der Extremismus im Strafrecht: Eine begriffsanalytische Analyse auf sozialwissenschaftlicher und verfassungsrechtlicher Grundlage / Matthias Ermert. - Herbolzheim: Centaurus-Verl., 2007. Zugl.: Mainz, Univ., Diss. pp. 36.

Antonyan, Yu.M. (2008) The extremism nature//Criminal and legal prohibition and its efficiency in the fight against modern crime / the Collection of scientific works under the editorship of H.A. Lopashenko. Saratov. pp. 246.

Arestov, V.N. (1987) Religious extremism (contents, reasons and forms of manifestation, a way of overcoming). - Harkov: The higher school. pp.34-35.

Arestov, V.N. (1987) Religious extremism: contents, reasons and forms of manifestation, a way of overcoming. Kharkov.

Arukhov, Z.S. (2001) Extremism in Modern Islam / Alima and scientists against Wahhabism: collection. Makhachkala. pp. 45.

Burkovskaya, V.A. (2005) Criminal religious extremism in modern Russia. - M.: Institute of legal and comparative researches, 2005. pp. 34.

Verkhovsky, A. Who here, extreme? The Russian religious radicalism in determinations//www.religion.ng.ru

Verkhovsky, A., Pine, A. \& Pribylovsky, V. (1996) Political extremism in Russia. M.

Volkov, V.V. (2002) Politichesky radicalism in Islam and national security of Russia. Abstract of the thesis of the candidate of political sciences. $\mathrm{M}$.

Voronov, I.V. (2003) Bases of political-legal limit of social, political extremism as threats of the national security of the Russian Federation. Abstract of the thesis of the candidate of political sciences. M. 
Galperin, B.I. (1989) Religious extremism: who is who. Kiev. pp. 7.

Gorshenkov, G.N. (2008) To the question of the essence of extremism as criminal and legal and criminological phenomenon//Gaps in the Russian legislation. No. 1. pp. 297-299.

Dobayev, I.P. (2000) Political radicalism in modern Islam (on materials of the Middle, Middle East and the North Caucasus), Abstract of the thesis of the candidate of political sciences. Rostov-on-Don.

The agreement between the Republic of Tajikistan, the Republic of Kazakhstan, the Kyrgyz Republic and the Republic of Uzbekistan on joint actions on fight against terrorism, political and religious extremism, the transnational organized crime and other threats to stability and safety//Akhborimadzhlisi Olya of the Republic of Tajikistan (2000) №10, Art. 442.

Zhuravsky, A. Religious extremism:reality or fiction?//www.sedmiza.ru

The law of the Republic of Tajikistan "About fight against terrorism" of November 16, 1999 (1999) Akhbori of Majlisi Oly of the Republic of Tajikistan. №11, Art. 275.

The law of the Republic of Tajikistan "About fight against extremism" of December 8, 2003 (2003) Akhbori of Majlisi Oly of the Republic of Tajikistan. №12, Art. 697.

The law of the Republic of Tajikistan "About public associations" of May 12, 2007 (2007) Akhbori of Majlisi Oly of the Republic of Tajikistan. №5, Art. 363.

The law RT "About Political Parties" of November 13, 1998 (1998) Akhborimadzhlisi Olya of the Republic of Tajikistan. №22, Art. 300.

The law RT "About the Freedom of Worship and Religious Associations" of March 26, 2009 (2009) Akhborimadzhlisi Olya of the Republic of Tajikistan. №489, Art. 739.

Ignatenko, A. (2004) Islam and Policy. M. pp. 107.

Kovalyov, B.C. (2004) Political extremism and the mechanism of counteraction to it in modern Russia. Abstract of the thesis of the candidate of political sciences. M, 2003. Mukhabbatov K.M. Socio-political factors of the formation of the religious political organization "Hizb-ut-Tahrir" and its reactionary essence (on materials of Tajikistan): Abstract of the thesis of the candidate of political sciences. Dushanbe. pp. 19.

Kozlov, A.P. (2004) Concept of the crime. SPb., Legal Press Center Publishing house. pp. 198.

Canons, A.I. \& Novels, H.A. (1994) The general characteristic of political extremism in modern conditions.

Constitution of the Republic of Tajikistan (2004) Dushanbe: Matbuot.

Korovnikov, A.V. (1990) Islamic extremism in the Arab countries. M. pp. 11-12.

Short political dictionary (1989) M.: Political Literature. pp. 275.

Kruglov, E.V. (2003) On the issue of socio-psychological nature of right-wing extremism (on the example of modern Britain) // Bulletin of the Russian Peoples' Friendship University. - Ser .: Politics. № 4. pp. 93-99.

Kuntz, Je.W. (1998) Crime because of the international and religious conflicts and criminal legal measures of fight against it: Thesis of the candidate of jurisprudence. - Chelyabinsk. pp. 45.

Luneev ,V.V. (2005) Crime of the 20th century: world, regional and Russian tendencies. Prod. The 2nd. M. pp. 633.

Nazirov, D. (2007) Religiouspolitical extremism and terrorism in Central Asia. Dushanbe: Irfon. pp. 28.

Namatov, N. Religious extremism in Central Asia//www.ca-c.org/datarus/namatov.shtml. pp. 2.

Nekrasov, D.E. (2007) Racial and ethnic extremism: criminological aspect. The thesis of the candidate of jurisprudence. Ryazan. pp. 14.

Ojegov, S.I. (2002) Dictionary of Russian. M. pp. 797.

Pavlinov, A.V. (2008) Antistate extremism: criminal and legal and criminological aspects. M: Yurlitinform. pp. 47.

Rzhev, A.C. (2004) Extremism and its manifestations in the Criminal Code of Russia (the criminal and legal characteristic). The thesis of the candidate of jurisprudence. Rostov-on-Don. pp. 17.

Romanov, N.A. (1997) Political extremism as a threat to the security of Russia: Thesis of the doctor of political sciences. M. pp. 37.

Romanov, N.A. (1991) Essence and maintenance of political extremism. M.

Soloviev, A.B. (1990) Political extremism in modern Russia: the middle of the 1980th - the 1990th years. Abstract of the thesis of the candidate of political sciences. N. Novgorod, 1998. Verkhovsky A., Mikhaylovskaya E., Pribylovsky V. Political xenophobia.

Syukiyaynen, L. (2002) Religious extremism: legal, political and ideological aspects. Religious extremism in Central Asia: problems and perspectives//conference Materials: Dushanbe. pp. 22.

The criminal code of the Republic of Tajikistan of May 21, 1998 (2004) Dushanbe: Konuniit.

Uzdenov, R.M. \& Pudovochkin, Yu.E. (2008) Theoretical designs of determination of extremism: problems and perspectives/l Criminological magazine. No. 8. pp. 84.

Fridinsky, S.N. (2003) Fight against extremism (criminal and legal and criminological aspects): Thesis of the candidate of jurisprudence. Rostov-on-Don. pp. 33.

Fridinsky, S.N. (2004) Fight against extremism: criminal and legal, criminological aspects. M. pp. 6.

Fridinsky, S.N. (2003) Fight against extremism: Criminal and legal and criminological aspects: Abstract of the thesis of the candidate of jurisprudence. (12:00. 08). Rostov-on-Don. pp. 8.

Fridinsky, S.N. (2003) Criminal and legal and criminological characteristic of crimes of the extremist orientation: Abstract of the thesis of the candidate of jurisprudence. Rostov-on to Don. pp. 14.

Hlebushkin, A.G. (2007) Criminal Extremism: concept, types, problems of criminalization and penalization. The thesis of the candidate of jurisprudence: 12.00.08. M. pp. 18-19.

Hlebushkin, A.G. Criminal Extremism: concept, types, problems of criminalization and penalization. pp. 19.

Hlobustov, O. M. \& Fedorov, S.G. (2000) Terrorism: the reality of today's state//Modern terrorism: state and perspectives. Under the 
editorship of E.I. Stepanov. M.: Editorial of URSS. pp. 86.

Chebotaryov, G.N. (2011) Moral legal basis of the fight against extremism. The legal basis of counteraction of extremist activity//Materials All-Russian scientific and practical conference: Tyumen. pp. 11.

The Shanghai Convention on the fight against terrorism, separatism and extremism of July 15, 2001 (2003) The Collection of the international acts on the fight against terrorism. Dushanbe. 